\title{
AKTIFITAS PRODUKSI DALAM PERSPEKTIF EKONOMI ISLAM
}

\author{
Akhmad Mujahidin*
}

\begin{abstract}
A bstract: Economic activities contain three parts, namely production, distribution, and consumption. This paper deals with the first one in the perspective of Islam. We maintain that at no point in human history was there any economic system that could successfully achieve an absolute happiness and wellbeing for human kind. Islamic system of economics included. Nonetheless, we argue that Islam consists of values and norms that may lead toward that end if they are properly and appropriately understood and applied. We do not find in Islam what we found in the conventional economic system where there are rooms for committing corruption and manipulation. For Islam, economic activities as far as production is concerned must be directed toward achieving the goodness and prosperity of all human kind, and not toward enriching certain individuals and groups among individuals.
\end{abstract}

Keywords: economic activities, production, Islamic values, prosperity

\section{Pendahuluan}

Ekonomi merupakan bagian vital yang tak dapat dipisahkan dari kehidupan manusia. Siapa pun orangnya, dari suku manapun, dari bangsa manapun, agama apapun, tidak akan terlepas dari aspek yang satu ini. Bagaimana tidak, sejak manusia dilahirkan, ia sudah memiliki banyak kebutuhan yang harus dipenuhi.

Secara umum, kegiatan ekonomi dapat dibagi menjadi tiga macam, yaitu produksi, distribusi dan konsumsi. Dalam dunia modern, dikenal pula adanya intermediasi dan kebijakan pemerintah. Selain itu, semua ini bergantung pula kepada tenaga kerja, sumber daya alam, manajemen dan lain sebagainya. Kesemuanya ini membentuk sebuah sistem yang rumit yang biasa disebut dengan kegiatan ekonomi. Sistem ini memiliki satu tujuan utama; kesejahteraan manusia. Bila sistem ini kacau, maka dapat dipastikan kehidupan manusia akan kacau pula.

Penulis berpendapat, bahwa sepanjang sejarah manusia belum ada sistem hasil pemikiran manusia yang telah terbukti mampu menciptakan kesejahteraan absolut dan sempurna. Barangkali ada beberapa era dalam sejarah yang pernah tercatat sebagai era gemilang dalam menyejahterakan manusia, namun era tersebut tidak berlangsung lama, kemudian sistem tersebut hancur dengan sendirinya oleh ulah pembuat dan pelakunya.

Begitu pun halnya dengan sistem ekonomi yang mendominasi dunia saat ini; sistem ekonomi kapitalis. Fakta di dunia modern mencerminkan, bahwa sistem ini telah membuat kesenjangan yang begitu radikal di antara manusia, di mana hampir $20 \%$ penduduk dunia menikmati $80 \%$ hasil kekayaan yang ada di bumi, sedangkan $80 \%$ penduduk dunia lalu memperebutkan 20 sisa kekayaan tersebut. Di beberapa negara makmur, orang menikmati hidup berkecukupan dan berkelebihan. Sementara di banyak belahan dunia, terdengar pula jerit kelaparan dan kesakitan.

* Dosen Ekonomi Islam Fakultas Syari'ah dan IImu Hukum UIN Sultan Syarif Q asim, Riau. 
IImu ekonomi Islam adalah pengetahuan dan aplikasi ajaran-ajaran dan aturan-aturan shari $a_{h}$ yang mencegah ketidakadilan dalam pencarian dan pengeluaran sumber-sumber daya guna memberikan kepuasan bagi manusia dan memungkinkan mereka melaksanakan kewajibankewajiban mereka terhadap Allah dan masyarakat.

\section{Hakikat Ekonomi Islam.}

Dalam filsafat ilmu, ilmu atau sains dibagi dalam tiga bagian, yaitu O ntologi, Epistimologi dan Aksiologi. ${ }^{1}$ Yang dimaksud dengan O ntologi adalah segala sesuatu yang bertalian dengan terbentuknya ilmu. Epistemologi adalah makna ilmu yaitu tentang seluk beluk ilmu itu sendiri, apa kemampuan dan keterbatasannya. Aksiologi adalah segi guna laksana dari ilmu, yakni halhal yang berkenaan dengan upaya untuk meningkatkan kesejahteraan hidup. ${ }^{2}$

Ditinjau dari aspek Ontologi, ekonomi konvensional menggunakan landasan filsafat Positivisme yang berdasarkan pada pengalaman dan kajian empiris (hanya mengandalkan ayatayat kawniyah saja), dan tidak percaya kepada petunjuk Tuhan (sekuler). Dalam ekonomi sekuler, kesenangan atau kebahagian yang dikejar adalah semata-mata kebahagian di dunia saja dan sangat materialistik. Mereka tidak memandang bahwa apa-apa yang dikerjakan mempunyai dampak di akhirat. Sedangkan ekonomoi Islam, yang menjadi pedoman utama adalah petunjuk Allah berupa wahyu (al-Qur'aø). Al-Sunnah, Q iyas, ljmasdan ljtihad serta ayat-ayat kawniyah yang bertebaran di jagat raya. Dalam hal penggunaan ayat-ayat kawniyah, umat Islam harus hati-hati, karena seringkali karena dorongan hawa nafsu, manusia banyak tertipu oleh penglihatan, pendengaran dan akal sehingga jauh dari kebenaran wahyu. ${ }^{3}$

Dengan demikian dalam ilmu Ekonomi konvensional yang mendorong untuk melakukan kegiatan ekonomi adalah Self-Interest. Artinya, apa yang dilakukan semata-mata untuk kepentingan pribadi. Sedangkan dalam Islam yang menjadi pendorong kehendak Allah (GodInterest) yaitu dalam rangka mengabdi dan mencari ridha Allah Swt.

Secara Epistemologis, ekonomi berasal dari oikonomia (Greek atau Yunani). Kata oikonomia berasal dari dua kata oikos yang berarti rumah tangga dan nomos yang berarti aturan. J adi ilmu ekonomi adalah ilmu mengatur rumah tangga, yang dalam bahasa Inggris disebut sebagai economics. ${ }^{4}$ Kata economics ini, tidak ditemukan dalam al-Q ur'an. Menurut H ans Wehr, "A Dictionary of Modern Written Arabic" (1961) yang diedit oleh J. Milton Cowan, dijumpai kata dasar "qa sła da", yang melahirkan "qasфll" (yang berarti;endeavor, aspiration, intentions, intent, design, purpose, resolution, object, goal, aim, end; frugality; thrift dan economy); "qasłlan" (intentional; intended); "qasid" (aspired, desired, aimed at, intended); "maqsid" atau "maqasid" (destination); dan "iqtishad" (saving, economization, retrenchment; thriftiness, thrift, providence; economy). ${ }^{5}$ Dari sini lahirlah istilah 'ilm al-iqtisłd (ilmu ekonomi); 'ilm al-iqtisłd al-siyasi łpolitik

\footnotetext{
${ }^{1}$ Depag RI, Pedoman Pembukaan dan Penyelenggaraan Program Studi Ekonomi Islam pada Perguruan Tinggi Agama Islam (J akarta: Dirjen Bagais, 2005), 4-8.

2 J ujun S. Suriasumantri, Filsafat Ilmu Sebuah Pengantar Popoler (J akarta: Pustaka Sinar Harapan, 2001), 63-253, lihat juga The Liang Gie, Pengantar Filsafat IImu (Yogyakarta: Liberty, 1991), 1-27.

${ }^{3}$ Thahir Abdul Muhsin Sulaiman, Menanggulangi Krisis Ekonomi secara Islami (Bandung: Al-Ma'arif, 1985), 29.

${ }^{4}$ Samuelson, IImu Makro Ekonomi (J akarta: Media G lobal Edukasi, 2004), 3.

${ }^{5} \mathrm{H}$ ans Wehr, A Dictionary of M odern Written Arabic, ed. J . Milton Cowan (J erman: B uchdruckerel Hubert, 1961), 898.
} 
ekonomi), iqtisłdan fi al-waqf (in order to save time) dan al-iqtisłdiyah (the economy)

Secara terminologi, Samuelson merumuskan, "ilmu ekonomi didefinisikan sebagai kajian tentang prilaku manusia dalam hubungan dengan pemanfaatan sumber-sumber prospektif yang langka untuk memproduksi barang-barang dan jasa-jasa serta mendistribusikannya untuk dikomsumsi". ${ }^{6}$

Dalam perkembangannya, kata rumah tangga tidak semata-mata dalam keluarga yang berarti suami-istri dan anak-anaknya, tetapi rumah tangga digunakan secara luas yaitu rumah tangga masyarakat dan rumah tangga negara. Ini berarti bahwa kegiatan itu melibatkan anggota keluarga yang mampu menghasilkan barang dan jasa, pada gilirannya seluruh anggota keluarga yang ada ikut menikmati apa yang mereka peroleh. Kegiatan ini kemudian menyebar ke seluruh populasi rumah tangga yang kemudian menjadi kelompok yang diperintah oleh pemerintahan suatu negara. Pengaturan rumah tangga ini mencakup tiga sub sistem, yaitu memperbanyak kekayaan dan memelihara keberadaannya yang disebut dengan sub sistem produksi, tata cara mengkomsumsikannya disebut sub sistem konsumsi produksi, dan yang berhubungan dengan tata cara pendistribusiannya yang tercakup dalam sub sistem distribusi.

Berdasarkan istilah ruang lingkup ekonomi sebagaimana tersebut di atas, maka Islam sebagai sebuah agama yang mengatur segala aspek kehidupan, tentu saja mempunyai cara untuk berekonomi. Dalam kaitan ini Yusuf H alim al-'Alim mendefinisikan ilmu ekonomi Islam sebagai ilmu tentang hukum-hukum shari'gh aplikatif yang diambil dari dalil-dalil yang terperinci terkait dengan mencari, membelanjakan, dan cara-cara membelanjakan harta. Definisi ini menunjukkan bahwa fokus kajian ekonomi Islam adalah mempelajari prilaku muamalah masyarakat Islam yang mengikuti al-Qur'an, al-Sunnah, Qiyas dan Ijma'>dalam memenuhi kebutuhan hidupnya untuk mencari ridł Allah.

Ditinjau dari aspek Aksiologi, tujuan ekonomi Islam adalah bahwa setiap kegiatan manusia didasarkan kepada pengabdian kepada Allah dan dalam rangka melaksanakan tugas dari Allah untuk memakmurkan bumi, maka dalam berekonomi umat Islam harus mengutamakan keharmonisan dan pelestarian alam. Kebahagian yang dikejar dalam Islam bukan semata-mata kebahagiaan di dunia saja, tetapi juga kebahagiaan di akhirat kelak. ${ }^{8}$ Dengan demikian ilmu ekonomi Islam harus mempunyai sistem ekonomi yang dapat memakmurkan bumi, mampu membahagiakan manusia baik selama hidup di dunia maupun di akhirat kelak.

\section{Spirit al-Q ur'an tentang Ekonomi.}

Al-Qur'aß banyak menyimpang gagasan-gagasan ekonomi. Dengan mempertimbangkan "Sunah Rasul". Para ulama dan pemikir muslim telah mengembangkan dan melengkapi gagasan tersebut dengan rincian-rincian yang secara eksplisit dan khusus tidak dijelaskan, sehingga

\footnotetext{
${ }^{6}$ Samuelson, Ilmu Makro, 5.

${ }^{7}$ Yusuf H alim al-'Alim, al-Nizłm al-Siyasi wa al-Iqtisłd fi al-Islam, I (Beirut: Dasal-Q alam, 1975), 19.

${ }^{8}$ Adiwarman Karim, Ekonomi M ikro Islami (J akarta: IIIT Indonesia, 2002), 22. Tujuan ilmu ekonomi konvensional adalah untuk menyejahterakan umat manusia. Namun dorongan self-interest yang melandasi ekonomi konvensional yang diperparah sifat-sifat manusia yang individualistik dan serakah (hedonistic) telah mengakibatkan terjadinya eksploitasi antar sesama manusia, antar kelompok bahkan antar bangsa. Untuk mewujudkan kepentinggannya, setiap orang, kelompok atau bangsa menggunakan prinsip dengan pengorbanan yang sesedikit mungkin untuk mendapatkan sebanyak mungkin. Selain eksploitasi antar sesama manusia, prinsip ini juga telah mengakibatkan
} 
menjadi seperangkat aturan-aturan dan ajaran-ajaran sharißah melandasi secara teoritis seluruh kegiatan ekonomi, termasuk produksi.

Kisah "Zulkarnain" dalam al-Qur'an suratal-Kahf, ayat 92 s/d ayat 97, memberikan gambaran bagaimana masing-masing faktor produksi berfungsi dalam satu kegiatan produksi.

"Kemudian dia menempuh suatu jalan (yang lain lagi). Hingga apabila dia telah sampai di antara dua buah gunung, dia mendapati di hadapan kedua bukit itu suatu kaum yang hampir tidak mengerti pembicaraan. Mereka berkata: "Hai Dzulqarnain, sesungguhnya Ya'juj dan Ma'juj itu orang-orang yang membuat kerusakan di muka bumi, maka dapatkah kami memberikan sesuatu pembayaran kepadamu, supaya kamu membuat dinding antara kami dan mereka?" Dzulqarnain berkata: "Apa yang telah dikuasakan oleh Tuhanku kepadaku terhadapnya adalah lebih baik, maka tolonglah aku dengan kekuatan (manusia dan alat-alat), agar aku membuatkan dinding antara kamu dan mereka, berilah aku potongan-potongan besi" Hingga apabila besi itu telah sama rata dengan kedua (puncak) gunung itu, berkatalah Dzulqarnain: Tiuplah (api itu)". Hingga apabila besi itu sudah menjadi (merah seperti) api, diapun berkata: "Berilah aku tembaga (yang mendidih) agar kutuangkan ke atas besi panas itu".

Ayat-ayat 92-97 dari surat al-Kahf ini diangkat Thahir Abdul Muhsin Sulaiman untuk menegaskan konsep yang diformulasikan al-Qur'an bagi proses produksi. la menyatakan "sebuah contoh yang lengkap dari sebuah usaha produksi adalah kisah al-Qur'an tentang Zulkarnain di mana ia menjadi seorang manajer dan perencana dalam membuat dinding. ${ }^{9}$

Sarana hukum yang dilakukan Islam untuk meningkatkan produktivitas dan mengikis kemalasan atau menyia-nyiakan berbagai sumber akan terlihat jelas dalam rangkuman berisi dua puluh pernyataan yang diberikan oleh al-Sadr berikut ini: 1) Pemerintah akan merampas hak atas tanah dari pemiliknya bila dia tidak memanfaatkan dan tidak mengolah ataupun menggunakannya untuk kepentingan lain. Negara tidak akan membayar imbalan dan akan menetapkan tanah itu sesuai dengan keputusannya yang terbaik, 2) Penguasaan atas tanah yang tidak diketahui pemiliknya tidak menimbulkan hak atas tanah tersebut, yang ada hanyalah pemanfaatan secara baik, 3) Tidak ada sumber-sumber alam milik pribadi yang boleh dibiarkan tanpa dimanfaatkan. Tidak digunakannya sumber-sumber alam itu bisa mengakibatkan tidak sahnya tuntutan pemilikan pribadi atas sumber-sumber tersebut, 4) Tanah negara bisa diberikan kepada lembaga-lembaga atau badan-badan swasta sesuai kemampuan masing-masing untuk memanfaatkannya, 5) Semua jenis kegiatan perantara yang tidak produktif dilarang, misalnya menyewa dengan tarif yang lebih tinggi, 6) Bunga dilarang dipungut sebagai sumber penghasilan yang dijaminkan kepada orang-orang yang sebenarnya tidak terlibat dalam kegiatan produktif, 7) Kegiatan-kegiatan yang tidak produktif secara ekonomik seperti perjudian atau permainan majig, atau sihir dilarang, 8) Penyimpanan uang atau benda-benda bergerak lainnya dikenakan kewajiban pembayaran zakat 2,5 persen setiap tahun, 9) Penggunaan alkohol, obat-obat bius, dan semua keberandalan yang dapat mempengaruhi sensibilitas orang dan kemampuannya

terjadinya eksploitasi alam yang berlebihan yang pada akhirnya menimbulkan kerusakan, baik dalam bentuk kemarau yang berkepanjangan, banjir, longsor, polusi udara, kelangkaan air bersih dan lain-lain. Lihat, Syed Nawab Haider Naqvi, M enggagas IImu Ekonomi Islam (Yogjakarta: Pustaka Pelajar, 2003), 28.

${ }^{9}$ Lihat Sulaiman, Menanggulangi, 139. 
untuk melaksanakan kegiatan produktif dilarang, 10) Penetapan aturan yang menjurus kepada pragmentasi kekayaan yang terpusatkan secara terus menerus dan secara perlahan-lahan dinyatakan tidak sah, 11) Spekulasi dibatasi dan transaksi-transaksi yang semata-mata bersifat spekulasi baik dalam pasar uang maupun komoditas dilarang, 12) Hukum waris harus dipergunakan sebagai perangsang terhadap kegiatan-kegiatan produktif dan pada saat yang sama siapa saja tidak dibenarkan oleh Islam untuk memilih ahli-ahli warisnya sendiri yang sah atau mengurangi jumlahnya merupakan sarana yang menentang pemusatan kekayaan, 13) Seharusnya ada jaminan sosial dalam hubungannya dengan tingkat kehidupan yang terjamin secara wajar dan kemungkinan membayar hutang-hutang yang secara wajar terjamin pula, 14) Ketidaksediaan bekerja dan kemalasan yang disengaja menyebabkan orang yang bersangkutan tidak berhak mendapatkan jaminan sosial, 15) Dengan dikuranginya kemewahan dalam konsumsi pribadi menyebabkan pengeluaran dalam investasi yang menyimpang lebih menarik, 16) Kewajiban bersama umat Muslim adalah mengajarkan setiap cabang pengetahuan dan industri yang bermanfaat, 17) Kewajiban bersama umat Muslim adalah ikut berpartisipasi dalam industri-industri besar dan berbagai bidang pengetahuan di dunia, 18) Negara memiliki peran besar dalam produksi, dalam kaitannya dengan perencanaan dan perusahaan negara, 19) Negara diperbolehkan memperoleh berbagai sumber dan mendistribusikannya dalam rangka memaksimisasikan realisasi tujuan-tujuan normatfe masyarakat, 20) Negara masuk dalam bidang kegiatan ekonomi sebagai perencana dan pengawas utama. ${ }^{10}$

M.A. Mannan menjelaskan prinsip produksi dalam sistem ekonaomi Islam sebagai berikut. "Prinsip fundamental yang harus diperhatikan dalam proses produksi adalah prinsip kesejahteraan ekonomi. Bahkan dalam sistem ekonomi kapitalis terdapat seruan untuk memproduksi barang dan jasa yang didasarkan pada asas kesejahteraan ekonomi. Keunikan konsep Islam mengenai kesejahteraan ekonomi terletak pada kenyataan bahwa hal itu tidak dapat mengabaikan pertimbangan kesejahteraan umum lebih luas yang menyangkut persoalan-persoalan tentang moral, pendidikan, agama, dan banyak hal lainnya. ${ }^{11}$

\section{Akitifitas Produksi}

Kata "produksi" telah menjadi kata Indonesia, setelah diserap ke dalam pemikiran ekonomi bersama dengan kata "distribusi", dan "konsumsi". Dalam kamus bahasa Inggris Indonesia oleh John M. Echols dan Hassan Shadily kata production secara linguistik mengandung arti penghasilan, ${ }^{12}$ dan didefenisikan oleh HRA Rivai Wirasasmita sebagai proses peningkatan kapasitas barang-barang untuk memuaskan keinginan atau kebutuhan manusia atau proses pembentukan jasa-jasa yang mampu memuaskan kebutuhan-kebutuhan manusia. Dalam ilmu ekonomi formal, yang salah satu topik utamanya adalah masalah produksi, umumnya diakui bahwa utilitas (daya guna) atau kesanggupan suatu benda meteriil untuk memuaskan kebutuhan manusia dapat ditingkatkan dengan penciptaan utilitas waktu, utilitas tempat/letak, utilitas bentuk, atau utilitas pemilikan. ${ }^{13}$

${ }^{10}$ Dikutip oleh Kahfi, 34.

${ }^{11}$ M.A. Mannan Ekonomi Islam: Teori dan Praktek, alih Bahasa Pafat Arif H arahap (J akarta: Intermasa 1992), 54.

${ }^{12} \mathrm{~J}$ ohn M. Echols dan Hassan Shadily, Kamus Inggris Indonesia, Cet. 23 (J akarta: PT. G ramedia, 1996), 449.

${ }^{13}$ HRA Rivai Wirasasmita, dkk., Kamus Lengkap Ekonomi (Bandung: Pionir J aya, 2002), 394. 
Dalam literatur Ekonomi Islam berbahasa Arab padanan produksi adalah kata intaj dari akar kata nataja. ${ }^{14}$ Maka "Produksi dalam Perspektif Ekonomi Islam" sebagaimana judul tulisan ini diterjemahkan ke dalam bahasa Arab, susunannya menjadi; al-Intaj fi \Marizur al-Islam (Production in Islamic Perspective).

Produksi dengan maknanya yang dikenal dalam ilmu ekonomi sekarang ini merupakan terminologi baru. Terminologi ini tidak mengandung makna kontemporernya dalam satu fase, namun melalui beberapa fase sebelum menjadi terminologi yang baku seperti sekarang ini. ${ }^{15}$ Lembaga-lembaga ekonomi konvensional; mulai dari para pelaku perdagangan hingga para ahli alam hanya membatasi makna produksi pada sebagian aktifitas, dan tidak pada sebagian yang lain. Sebab para pelaku perdangangan berpendapat bahwa perdagangan eksternal sebagai satu-satunya aktifitas yang menghasilkan. ${ }^{16}$ Lalu datang para ahli ilmu alam, dan mereka berpendapat bahwa pertanian merupakan aktifitas ekonomi yang menghasilkan. Mereka menilai perdagangan dan industri merupakan dua kegiatan yang mandul. Dan, definisi produksi -dalam ekonomi konvensional- tidak baku seperti sekarang ini melainkan dalam abad $19 \mathrm{M}$. Di mana datang kaum tradisional baru yang mengaitkan produksi dengan kemanfaatan. Hingga setiap bentuk aktifitas ekonomi yang mendatangkan kemanfaatan atau menambahkannya dinilai sebagai aktifitas produksi. Dan termasuk dalam makna ini produksi jasa dengan segala bentuk. ${ }^{17}$

Al-Q ur'an mempergunakan konsep produksi dalam arti yang sangat luas. Al-Qur'an sangat menekankan pemanfaatan barang-barang yang diproduksi. Barang-barang tersebut harus berhubungan dengan kebutuhan manusia. Barang-barang itu harus juga diproduksi dengan tujuan untuk memuaskan kebutuhan manusia dan bukan merupakan barang-barang mewah. J ika barang-barang tersebut tidak memenuhi kebutuhan hidup manusia, maka tenaga kerja yang dihabiskan untuk memproduksi barang semacam itu dianggap tidak produktif. Dalam keadaan bagaimanapun, al-Q ur'an tidak membenarkan adanya produksi barang-barang mewah, dan tenaga kerja manusia yang dihabiskan untuk memproduksi barang-barang dianggap sebagai penghamburan usaha manusia. Al-Qur'an dengan cara yang bijaksana telah memberikan lapangan yang sangat luas bagi usaha manusia dengan memberi santapan rohani pada manusia

\footnotetext{
${ }^{14}$ Menurut Nazih Hamad istilah intaj yang menunjuk pada makna produksi tidak dikenal dalam literatur fiqi. Lihat $\mathrm{N}$ ajih Hamad, M u'jam al-M ustalahat al-Fiqh Iqtisædiyłah fi Łughat al-Fuqaha'>(Kairo: al-Ma'had al-'A lami li al-Fikr alIslamii>1993),74. Hal ini menurut hemat penulis disebabkan para fuqahaStidak membahas produksi sebagaimana yang dikenal dalam kajian ekonomi Islam modern, mereka lebih tertarik menggunakan kata "tahsjik" untuk menunjuk makna hasil dari sesuatu usaha. Ibn Khaladun juga memperkenalkan kata "tahşip" untuk produksi ketika ia membahas pembagian spesialisasi tenaga kerja dengan mengatakan:"Sesungguhnya kemampuan seseorang sangat terbatas untuk memproduksi kebutuhan hidupnya sendirian". Lihat Ibn Khaladun, Muqaddimah, 35 dan 302.

${ }^{15}$ Produksi adalah setiap bentuk aktifitas yang dilakukan manusia untuk mewujudkan manfaatatau menambahkannya dengan cara mengeksplorasi sumber-sumber ekonomi yang disediakan Allah Swt. sehingga menjadi maslahat, untuk memenuhi kebutuhan manusia. Lihat, Muhammad Abdul Mun'im 'Afar dan Muhammad bin said bin $\mathrm{Naji}$ al-Ghamidi, Uskllbal-Iqtisład al-Islaami, $>59-60$.

${ }^{16}$ Adapun perdagangan internal maka sebagian mereka menilainya tidak menambahkan sesuatu. Sebab apa yang mendatangkan keuntungan satu fihak di dalamnya, berarti merugikan fihak yang lain.

${ }^{17}$ Lihatlah tahapan-tahapan yang dilalui definisi produksi dalam ekonomi konvensional dalam: DR. Sa'id alNajjar, Tarikth al-Fikr al-Iqtisłd, 29,35 dan 58, Labib Syuqair, Tarikkh al-Fikr al-Iqtisłd, 110-161,Abdurrahman Yasri

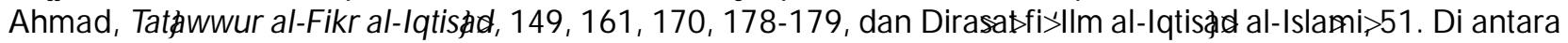
konsep Islam bahwa perbedaan makna produksi dalam ekonomi Islam dengan ekonomi konvensional adalah berkisar pada makna manfaat, batasan-batasannya, dan bidang-bidangnya. Dan demikian itu akan disebutkan kemudian dalam kajian ini.
} 
dalam memperoleh kekayaan yang lebih banyak lagi. Dengan kata lain, Islam berusaha untuk mengurangi sifat mementingkan diri dan sifat tamma' manusia dengan memberinya kesempatankesempatan yang tidak terbatas untuk melakukan aktivitas-aktivitas produksi.

Di dalam surat al-Ma'arij, karakter manusia, yang tampaknya merupakan dasar dari seluruh kegiatan ekonomi, diungkapkan dalam kata-kata ini.

"Sesungguhnya manusia diciptakan bersifatkeluh kesah lagi tamak" (QS: 70/al-M ua'rij),19.

Keserakahan dapat membuat seseorang selalu gelisah, tidak sabar, dan khawatir dalam memperoleh kekayaan material, dan dengan jalan itu merangsang melakukan kegiatan-kegiatan yang produktif. Manusia bekerja keras dan lebih giat lagi untuk memuaskan keinginannya yang terus meningkat, dan akibatnya ia seringkali membuat keajaiban-keajaiban dalam lapangan produksi.

J udul surat al-Ma'anij (Kenaikan yang Agung) meramalkan kemajuan manusia yang sangat besar dan tidak dibatasi dalam setiap bidang kehidupan. Ini mengandung arti bahwa manusia, dengan segala usaha yang dilakukannya secara konstan, akan membuat kemajuan besar dalam bidang ekonomi di alam ini. Watak serakah manusia memberi dorongan kuat yang, jika dituntun dengan baik, akan membawanya pada suatu kemajuan besar. Kemajuan manusia akan terus berlangsung selama manusia terus berjuang untuk memuaskan keinginannya yang bermacammacam itu. Kecerdasannya yang kreatif akan terus melahirkan dan meningkatkan metode serta teknik produksi baru. Ini akan menjaga standar pendapatannya dan dapat mengimbangi tuntutantuntutan zaman yang terus berubah.

Watak manusia dilukiskan dengan cara yang lain dalam surat Ali Imran:

"Dijadikan indah pada pandangan manusia kecantikan kepada apa-apa yang diingini, yaitu wanita, anak-anak, harta yang banyak dari jenis emas dan perak, kuda-kuda pilihan, binatang-binatang ternak dan sawah ladang Itulah kesenangan hidup di dunia, dan di sisi Allah-lah tempat kembali yang baik (surga)." (QS:3/ Ali Imron), 14.

Keinginan untuk memiliki sumber kekayaan dan kekuasaan adalah alamiyah. Manusia merasa tertarik akan emas dan perak (yang merupakan sumber-sumber produksi). Keinginan terhadap harta kekayaan (dan segala sesuatu yang mendukungnya) memberi rangsangan terusmenerus untuk usaha yang lebih besar. la berjuang untuk memuaskan keinginan-keinginannya yang terus meningkat. Karena keinginan-keinginan manusia tidak terbatas, maka perjuangannya untuk mendapatkan kepuasan semakin lama semakin besar. Oleh karena itu, pencarian kekayaan ini mutlak perlu dituntun dengan cara yang baik. J ika keinginan untuk mendapatkan harta itu tidak dituntun dengan baik, maka ia akan mengantarkan pada suatu kejahatan yang besar sebagaimana yang kita alami dalam masyarakat modern.

Salah satu faktor penting yang mengakibatkan munculnya kejahatan kapitalisme adalah sikap materialistis terhadap kehidupan, yang dilukiskan di dalam surat al-Ma'arij sebagai berikut.

"Serta yang mengumpulkan harta benda lalu menyimpannya" (QS: 70/al-Ma'arij), 18.

Keinginan untuk memiliki harta membuat manusia cenderung untuk menumpuk kekayaannya dan lalu menahannya agar tidak dipergunakan masyarakat. O rang semacam itu jarang memiliki rasa kepedulian terhadap kemaslahatan masyarakat umumnya. Mereka terusmenerus mengumpulkan kekayaan dalam jumlah yang besar. Sikap mementingkan diri sendiri 
manusia dalam bentuk kecintaan yang berlebih-lebihan terhadap harta telah dilukiskan di banyak tempat dalam al-Q ur'an. Dalam surat al-H umazah, pemilik modal digambarkan sebagai orang yang:

"Mengumpulkan harta dan menghitung-hitungnya" (QS: 104/ al-Humazah), 2.

Pemilik modal sedemikian dalamnya terlibat dalam lingkaran setan pengumpulan harta sehingga ia tidak akan pernah dapat ke luar dari lingkaran tersebut. la selalu sibuk menghitunghitung hartanya. Mereka hampir tak punya waktu untuk merenung dan memikirkan masalahmasalah lainnya yang sama atau bahkan lebih penting lagi. Sikap hidup seperti ini, di mana manusia menganggap kebutuhan materialnya sangat penting dan benar-benar mengabaikan aspek-aspek non-ekonomis dari kehidupan manusia,akan mengganggu keseimbangan masyarakat dan akhirnya mengakibatkan kemiskinan dan penderitaan terhadap keseluruhan komunitas.

Al-Qur'an memberi peringatan terhadap penumpukan harta dan kecintaan terhadapnya yang membabi buta dengan kata-kata:

"Sesungguhnya manusia itu sangat ingkar dan tidak berterima kasih kepada Tuhannya" (QS: 100/al-Adtiyat) 6.

Allah telah memberi karunia berupa kekayaan potensial yang sangat besar jumlahnya pada manusia agar ia dapat memanfaatkannya demi kebaikan diri dan komunitasnya, namun ia menjadi ingkar terhadap Tuhannya dengan menyalahgunakan karunia-Nya untuk tujuantujuan pribadinya saja. Dalam semangatnya untuk memperoleh harta yang lebih banyak, ia lupa akan hak orang lain dan sangat sering mengabaikan kemaslahatan umum. Kurangnya kesadaran manusia terhadap hak orang lain ini sesungguhnya merupakan sebab paling dasar dari semua kejahatan ekonomi dalam masyarakat modern yang akhirnya menyebabkan keruntuhan manusia itu sendiri. Tidak salah jika dikatakan bahwa individu (juga bangsa-bangsa) dapat berkembang dan meningkat sampai ke tingkat kemakmuran yang tinggi selama mereka tetap mempertahankan suatu keseimbangan yang baik antara tujuan-tujuan ekonomis dan nonekonomis; tetapi mereka akan jatuh ke dalam degradasi serta kehinaan segera setelah mereka melampaui batas keseimbangannya dan menyimpang pada salah satu sisinya.

Al-Q ur'aß secara diametral bertentangan dengan sikap asketis sebagaimana diajarkan oleh agama-agama lain, termasuk Kristen, Hindu dan Budha. Ajaran agama-agama asketisme tersebut mencela kekayaan dan sejumlah manfaatnya. Sejauh mungkin mereka menekan kebutuhankebutuhannya dan mengurangi segala aktivitas produktif. Sukses, menurut mereka, terletak pada usaha mengurangi segala keinginan dan hasrat; keinginan lebih pada yang satu dapat mengurangi kebutuhan seseorang, kesuksesan dan kepuasan yang lebih besar akan dicapai seseorang dalam kehidupannya. Kehidupan duniawi dengan segala manifestasinya dalam bentuk kekayaan dipandang rendah oleh mereka. Mereka mengklaim bahwa manusia tidak dapat mencapai kesucian dan kemuliaan di alam ruhani jika ia memperturutkan kehendaknya untuk memperoleh kekayaan atau aktivitas ekonomi lainnya. Dan setiap aktivitas ekonomi yang dilakukan manusia untuk memperoleh kekayaan guna memperturutkan kehendaknya untuk bersenang-senang demi kehidupan materi dan karenanya hal itu dikutuk oleh mereka.

Al-Qur'an dengan sangat tegas menentang pandangan ini. Al-Qur'an menekankan bahwa 
tidak ada pertentangan yang nyata antara pencarian material dan spiritual asal saja proporsinya tetap dipelihara di antara berbagai aktivitas manusia. Tidak ada pembagian aktivitas manusia yang dimasukkan ke dalam aktivitas spiritual dan material. Sesungguhnya, perhatian dan sikap di balik tindakan seseoranglah yang menentukan apakah itu spiritual atau material. Orang yang bertaqwa, yang melakukan kegiatan ekonomi untuk memenuhi kebutuhan-kebutuhan diri dan lebih baik secara spiritual dari pada orang yang terus menerus bersembahyang di sebuah tempat yang tersendiri tetapi ia menggantungkan kebutuhan-kebutuhan makanan, pakaian dan keperluan ekonomi lainnya pada orang lain.

Kitab Suci al-Qur'an memberi suatu pandangan hidup yang seimbang pada kita, yang menolong pertumbuhan kesehatan dan kecenderungan luhur di antara manusia di satu sisi, dan di sisi lain memberi dorongan pada aktivitas produktif mereka. Hal itu telah membuka lapangan yang luas untuk penelitian dan eksperimen yang dapat memberikan sumber-sumber kekayaan dan kekuatan yang tak terbatas. Kita sudah diberi tahu bahwa semua yang ada di dunia ini diciptakan untuk dimanfaatkan manusia. Binatang-binatang, bulan, matahari, dan bumi diciptakan untuk melayani umat manusia. Semua kekuatan alam raya ini berada di bawah kekuasaan manusia, jika ia mampu menggali manfaatnya. Dinyatakan secara jelas di dalam alQur'an bahwa manusia akan memperoleh apa yang diusahakannya. Kerja keras yang dilakukannya secara terus menerus dan sungguh-sungguh akan membuat ia mampu menemukan cara memanfaatkan sumber-sumber alam yang benar dan baik untuk kemaslahatan dirinya. AlQur'an sesungguhnya telah memberi dorongan yang besar pada manusia untuk melakukan percobaan dan menggali rahasia alam raya yang masih terpendam untuk dimanfaatkan manusia.

Mengingat sangat pentingnya aktivitas ekonomi dalam kehidupan manusia, al-Qur'an memperbolehkan perdagangan bahkan selama musim haji sekalipu.

"Tidak ada dosa bagimu untuk mencari karunia (rezki hasil perniagaan) dari Tuhanmu. M aka apabila kamu telah bertolak dari 'Arafat, berdzikirlah kepada Allah di M asy'arilharam dan berdzikirlah (dengan menyebut) Allah sebagaimana yang ditunjukkan-Nya kepadamu; dan Sesungguhnya kamu sebelum itu benar-benar Termasuk orang-orang yang sesat." (QS: 2/al-Baqarah), 198.

“Dengan demikian, perdagangan yang sah diperbolehkan, terutama bagi para pedagang yang jujur agar mereka dapat memenuhi biaya-biaya yang dibutuhkannya, dan bagi orangorang yang berhaji pada umumnya, yang mendapat kesulitan untuk memperoleh kebutuhankebutuhan hidupnya juga tidak dilarang berdagang. Penggunaan kata-kata 'karunia Allah' dengan jelas menunjukkan bahwa, 'perdagangan yang jujur dan baik' sesungguhnya adalah satu bentuk pelayanan pada masyarakat dan juga pada Allah." ${ }^{18}$ Pada surat al-J umu'ah dikatakan:

"A pabila telah ditunaikan salat, Maka bertebaranlah kamu di muka bumi; dan carilah karunia Allah dan ingatlah Allah banyak-banyak supaya kamu beruntung." (QS: 62/ alJumu'ah), 10.

Prinsip ajaran Islam yang fundamental, sebagaimana dijelaskan dalam ayat di atas, tegas menyatakan bahwa agama dan moralitas tidaklah bertentangan dengan kemakmuran dan

${ }^{18}$ Yusuf Ali, The Holy Qur'an, op. cit., hal. 79. note 219 
pencarian akan harta kekayaan. Namun sebaliknya, keduanya akan saling melengkapi dalam kehidupan bahagia. Haji merupakan suatu bentuk ibadah yang tidak melarang aktivitas ekonomi atau perdagangan bagi orang yang saleh - yaitu yang memperhatikan hukum Allah - yang coba memperoleh pengahasilan selama hari-hari tersebut (waktu pelaksanaan ibadah haji).

Orang-orang di bumi ini sering melakukan penyimpangan dari jalan lurus, baik dalam moralitas maupun aktivitas ekonomi. Mereka bersikap ekstrim dan melupakan jalan yang benar. Mereka sangat berlebih-lebihan dalam usaha memperoleh kebutuhan hidupnya yang bersifat ekonomi sehingga mereka benar-benar mengabaikan prinsip-prinsip moral, atau mengambil paham asketisme, yaitu meninggalkan kehidupan duniawi. Jalan yang benar antara kedua pandangan hidup yang ekstrim ini adalah jalan tengah, dan kehidupan yang benar-benar sukses akan datang pada seseorang yang mengatakan: "Inilah ajaran yang paling mulia, sebab Islam menganjurkan manusia untuk mencapai tujuannya dengan usaha keras. Islam mengharapkan agar seseorang bekerja keras untuk mencapai dan mempertahankan standar pendapatan yang tinggi. Islam tidak menginginkan perbudakan ekonomi manusia. Karena itu Islam menekankan pada manusia untuk berjuang dalam memperoleh harta". Suatu kali Nabi menerangkan: "Orang yang paling baik di antara kalian adalah orang yang tidak meninggalkan akhiratnya demi kepentingan dunia, dan juga tidak meninggalkan dunianya demi kepentingan akhiratnya dan tidak menjadi beban bagi masyarakat." Di sini Nabi telah memuji orang yang menjaga keharmonisan di dalam kebutuhan-kebutuhan hidupnya yang bermacam-macam dan tidak menjadi beban bagi orang lain.

Untuk mempercepat aktivitas ekonomi kaum Muslim dan memberi mereka waktu yang lebih banyak serta kesempatan yang lebih besar untuk maksud-maksud tersebut, maka kewajiban sạlat wajib (tengah malam) yang permanen dibatalkan oleh Allah dalam surat al-Muzammil. Demikian pula Nabi menyatakan bahwa: Perjuangan ekonomi seseorang demi keluarganya adalah sama dengan perjuangan dengan Nama Allah, dan ia dibebaskan dari kewajiban shalat J um'at berjemaah jika ia sibuk berusaha dalam mencari penghidupannya" (72:20)

Diriwayatkan bahwa Nabi pernah bersabda: "Semua Nabi yang terdahulu, sebelum aku menyibukkan diri mereka dengan berburu dan berpergian (di gurun pasir dan hutan-hutan) karena hanya dengan jalan ini mereka dapat memperoleh penghidupannya. Mengenai słlat jamaah, cukuplah bagi kamu - apabila kamu tidak hadir berjema'ah dikarenakan sibuk mencari penghidupan - jika kamu mencintai jama'ah, mencintai orang-orang yang sqat berjerma'ah, mencintai Asma'>Allah, mencintai orang-orang yang memuji Allah dan berkeinginan untuk memperoleh nafkah yang halal untuk keluarga. Semua hal itu cukup untuk menggantikan ketidakhadiran kamu dari berjema'ah. Hendaklah kamu berusaha untuk memperoleh nafkah yang halal bagi keluargamu, sebab itu sama dengan berjuang dengan Nama Allah"

Ada suatu hikayat di balik hadith tersebut, yaitu: "salah seorang sahabat bercerita pada Nabi bahwa berburu merupakan profesi dan sarana penghidupannya - dan ia tinggal di hutan belantara dan gurun pasir - maka ia sering ketinggalan berjema'ah shalat J um 'at." la lalu meminta nasihat dari $\mathrm{Nabi}$, yang suatu ketika pernah memperingatkan bahwa beliau akan membakar rumah-rumah mereka jika mereka meninggalkan shalatJ um'at berjema'ah, dan telah menolak pembebasan dari kewajiban berjemaah terhadap seorang laki-laki yang buta matanya, yang 
masih mampu mendengar panggilan adzan untuk słlat. Namun demi mendengar alasan ekonomi ini, Nabi berkata bahwa mereka hendaknya bekerja keras untuk memperoleh nafkah yang halal untuk keluarganya, sebab hal itu sama saja dengan berjuang dengan Nama Allah.

Sesungguhnya, Nabi telah memecahkan masalah ekonomi yang paling sulit di dunia ini. Beliau sesungguhnya telah menempuh suatu jalan terbaik di antara tindakan-tindakan yang melampaui batas. Dengan demikian beliau telah menetapkan suatu jalan yang jelas dan seimbang bagi orang-orang.

Ada banyak sabda Nabi yang menekankan perlunya berjuang untuk kebutuhan-kebutuhan material hidup ini. Di sini penulisd kemukakan beberapa sabda Nabi yang memberikan penekanan pada perjuangan ekonomi, "Usaha memperoleh penghasilan halal guna memenuhi kebutuhan hidup merupakan kewajiban penting kedua setelah kewajiban sक्षlat."

"A pabila kamu selesai sălat subuh, janganlah kamu tidur (istirahat) sampai kamu berusaha keras untuk memperoleh nafkahmu"

"Ada dosa-dosa tertentu yang dapat ditebus hanya dengan perjuangan yang terus menerus dilakukan untuk tujuan-tujuan ekonomi"

J ika kaum Muslim menuntutilmu dan beramal sesuai dengan ajaran-ajaran al-Qur'an dan Sunnah Nabi yang berkenaan dengan pemanfaatan sumber-sumber ekonomi negeri mereka, maka mereka pasti akan mengalami kemajuan yang lebih cepat dibanding bangsa-bangsa lain di dunia. Kemiskinan negeri-negeri Arab sangat terkenal pada masa kelahiran Nabi, tetapi kurang dari dua decade setelah hijrah ke Madinah, ketika doktrin ekonomi dari al-Q ur'an telah diterapkan pada masalah-masalah yang bersifat praktis pada waktu yang sangat singkat, bangsa yang miskin dan tertekan menjadi bangsa yang memimpin dunia di setiap bidang kehidupan. Ini merupakan hasil langsung dari diterapkannya ajaran-ajaran tentang ekonomi dari al-Qur'an terhadap masalahmasalah sehari-hari pada saat itu.

Penulis sepenuhnya yakin bahwa hasil yang sama di lapangan ekonomi dapat dicapai pada hari ini, jika konsep-konsep al-Qur'an dengan jelas dimengerti dan diterapkan dengan cermat serta adil sesuai dengan tuntutan dan kebutuhan zaman. Memang benar bahwa masalahmasalah kita banyak sekali dan sangat kompleks dibandingkan dengan yang ada pada masamasa sebelum kita, tetapi prinsip-prinsip dasar yang mengatur prilaku manusia, seperti yang terkandung di dalam al-Q ur'an adalah masih sama, dan jika diterapkan dengan cara yang cermat dan penuh penghayatan terhadap masalah-masalah modern, akan mampu melahirkan perubahan-perubahan revolusioner di bidang ekonomi sebagaimana yang telah terjadi sebelumnya.

Perbincangan tentang prinsip moral dalam produksi juga dikemukakan Yusuf Qardawi dalam bukunya "Norma dan Etika Islam", antara lain: 1) Berproduksi dalam lingkaran halal. Prinsip etika dalam produksi yang wajib dilaksanakan oleh setiap Muslim, baik individu maupun komunitas, adalah berpegang pada semua yang dihalalkan Allah dan tidak melewati batas. Benar bahwa daerah halal itu luas tetapi mayoritas jiwa manusia yang ambisius merasa kurang puas dengan hal itu walaupun banyak jumlahnya. Maka kita temukan jiwa manusia tergiur kapada sesuatu yang haram dengan melanggar hukum-hukum Allah, 2) Perlindungan kekayaan alam. Etika yang terpenting adalah menjaga sumber daya alami karena ia merupakan nikmat dari 
Allah kepada hambanNya. Setiap hamba wajib menyukurinya dengan menjaga sumber-sumber daya alam dari polusi, kehancuran atau kerusakan. Kerusakan di bumi terdiri dari dua bentuk, yaitu kerusakan materi misalnya, sakitnya manusia, termasuk tercemarnya alam, binasanya makhluk, terlantarnya kekayaan, dan terbuangnya manfaat. Adapun yang berbentuk spiritual adalah tersebarnya kezaliman, meluasnya kebatilan, kuatnya kejahatan, rusaknya hati kecil dan gelapnya otak. Kedua kerusakan ini adalah tindakan kriminal yang tidak diridai Allah. ${ }^{19}$

Pembahasan tentang faktor produksi dalam ekonomi Islam, menurut A.H.M. Sadeq, belum ada kesepakatan di antara penulis-penulis Muslim. Sebagian mereka menyebutkan empat faktor produksi: sumberdaya alam, sumber daya manusia, modal dan manajemen. Dan yang lain berpendapat bahwa faktor produksi hanya tiga: sumber daya alam, sumber daya manusia dan modal. ${ }^{20}$

Walaupun para pakar ekonomi Islam berbeda pandangan dalam menempatkan modal sebagai pokok produksi namun satu hal yang pasti adalah bahwa dua faktor produksi tanah dan tenaga kerja telah mendapat perhatian yang luas para penulis baik klasik maupun kontemporer. Menciptakan kesempatan produktif dengan membudidayakan tanah, yang dalam kajian keislaman klasik disebut ihya'‘al-mawat, merupakan sumber keuangan negara periode Rasulullah dan Khulafasal-Rashidia. ${ }^{21}$

Menurut Monzer Kahf, tujuan produksi adalah untuk meningkatkan kesejahteraan manusia tidak hanya kondisi materialnya, tetapi juga moralnya dan sebagai sarana untuk mencapai tujuannya di hari akhirat. $\mathrm{Hal}$ ini masih menurut Monzer, mempunyai tiga implikasi penting, yaitu:Pertama, produk-produk yang menjauhkan manusia dari nilai-nilai moralnya sebagaimana ditetapkan dalam al-Qur'an, dilarang semua jenis kegiatan dan hubungan industri yang menurunkan martabat manusia atau menyebabkan dia terperosok ke dalam kejahatan dalam rangka meraih tujuan ekonomi semata-mata, dilarang juga, Kedua, aspek sosial produksi ditekankan dan secara ketat dikaitkan dengan proses produksi. Sebenarnya distribusi keuntungan dari produksi di antara sebagian besar orang dan dengan cara seadil-adilnya adalah tujuan utama ekonomi masyarakat. Sistem ekonomi Islam lebih terkait dengan kesejahteraan masyarakat dibandingkan dengan sistem yang ada atau dengan berbagai tipe kapitalisme tradisional, Ketiga, masalah ekonomi bukanlah yang jarang terdapat dalam kaitannya dengan berbagai kebutuhan hidup tetapi ia timbul karena kemalasan dan kealpaan manusia dalam usahanya untuk mengambil manfaat sebesar-besarnya dari anugrah Allah baik dalam bentuk sumber-sumber manusiawi maupun sumber-sumber alami. ${ }^{22}$

\footnotetext{
${ }^{19}$ Yusuf Q ardawi, Norma dan Etika Ekonomi Islam, alih Bahasa Zainal Arifin, Dahlia H usin (J akarta: G ema Insani Press, 1997 ), 117-118.

${ }^{20}$ Lihat. A.H.M.Sadeq, Islamic Economic (Lahore: Dasat-Taaruf, 1981), 51. Bahkan Abu Saud menempatkan tanah, tenaga kerja, dan modal sebagai faktor produksi, Lihat Kahf, Op.cit., 39.

${ }^{21}$ Tidak terbantahkan lagi bahwa U mar dan para sahabat yang lain merupakan umat yang lebih tahu tentang berbagai ilmu shariłah, dan tidak kita dapatkan dalam pendapat mereka mayoritas definisi dan percabangan yang dibuat ulama untuk berbagai ilmu shariłah setelah masa sahabat dengan puluhan tahun. Di mana sebelum masa tersebut, ulama berbicara dari hafalan mereka dan meriwayatkan ilmu dari lembaran-lembaran yang tidak tersusun rapi. Lihat, Ibn Taghribardi, al-Nujum al-Złhirah (1: 351) dan disandarkannya kepada al-Dhahabi.

${ }^{22}$ Lihat Kahfi, Op.cit., 36-37.
} 


\section{Penutup}

Sesungguhnya kita tidak mendapatkan istilah produksi dalam buku-buku ekonomi karya ulama Islam klasik. Akan tetapi ketiadaan istilah ini tidak berarti ketiadaan substansi dan maknanya. Yang penting bahwa dalam ekonomi Islam tidak terjadi apa yang terjadi dalam ekonomi konvensional berupa kekeliruan dalam makna produksi dan pembatasan aktifitas produksi. Sebab ekonomi Islam sejak awal telah menetapkan hal ini. Di mana ekonomi Islam mengakui segala bentuk hasil produksi tanpa mengecualikan sesuatu pun darinya. Itu dapat dibuktikan dari banyaknya riwayat yang menjelaskan urgensi semua aktifitas produksi barang dan jasa yang dilakukan seorang muslim untuk memperbaiki apa yang dimilikinya, baik berupa sumber-sumber alam dan harta, dan dipersiapkan untuk bisa dimanfaatkan oleh pelakunya sendiri atau oleh umat Islam.

\section{Daftar Rujukan}

'Alim, Yusuf Halim al-. al-Nizam al-Siyasi wa al-Iqtisłd fi al-Islam, I. Beirut: Dasal-Q alam, 1975. Depag RI. Pedoman Pembukaan dan Penyelenggaraan Program Studi Ekonomi Islam pada Perguruan Tinggi Agama Islam. J akarta: Dirjen Bagais, 2005.

Echols, J ohn M. dan Hassan Shadily. Kamus Inggris Indonesia, Cet. 23. J akarta: PT. Gramedia, 1996.

Gie, The Liang. Pengantar Filsafat Ilmu. Yogyakarta: Liberty, 1991.

Hamad, Najih. M u'jam al-M ustälahat al-Fiqh Iqtisłdiłyah fi Łughat al-Fuqaha': Kairo: al-Ma'had al-'Alami li al-Fikr al-Islami>1993.

Karim, Adiwarman. Ekonomi Mikro Islami. J akarta: IIIT Indonesia, 2002.

Mannan, M.A. Ekonomi Islam: Teori dan Praktek, alih Bahasa Pafat Arif Harahap. Jakarta: Intermasa 1992.

Naqvi, Syed Nawab Haider. M enggagas Ilmu Ekonomi Islam. Yogjakarta: Pustaka Pelajar, 2003. Qardawiłusuf. Norma dan Etika Ekonomi Islam, alih Bahasa Zainal Arifin, Dahlia H usin. J akarta: Gema Insani Press, 1997.

Sadeq, A.H.M. Islamic Economic. Lahore: Dasat-Taaruf, 1981.

Samuelson. Ilmu Makro Ekonomi. J akarta: Media G lobal Edukasi, 2004.

Sulaiman, Thahir Abdul Muhsin. Menanggulangi Krisis Ekonomi secara Islami. Bandung: AlMa'arif, 1985.

Suriasumantri, J ujun S. Filsafat Ilmu Sebuah Pengantar Popoler. J akarta: Pustaka Sinar H arapan, 2001.

Wehr, Hans. A Dictionary of Modern Written Arabic, ed. J . Milton Cowan. J erman: Buchdruckerel Hubert, 1961.

Wirasasmita, HRA Rivai, dkk. Kamus Lengkap Ekonomi. Bandung: Pionir J aya, 2002. 